EXTENDED REPORT

\title{
Up regulated expression of tumour necrosis factor $\alpha$ converting enzyme in peripheral monocytes of patients with early systemic sclerosis
}

\author{
T Bohgaki, Y Amasaki, N Nishimura, M Bohgaki, Y Yamashita, M Nishio, K-i Sawada, S Jodo, \\ T Atsumi, T Koike
}

Ann Rheum Dis 2005;64:1165-1173. doi: 10.1136/ard.2004.030338

See end of article for authors' affiliations

Correspondence to:

Dr Y Amasaki, Department of Medicine II, Hokkaido

University Graduate

School of Medicine,

Address: N-15 W-7, Kita-

ku, Sapporo 060-8638,

Japan; yamasaki@

med.hokudai.ac.jp

Accepted

28 December 2004

\begin{abstract}
Background: Systemic sclerosis (SSc) is accompanied by abnormalities in humoral and cellular immune systems.

Objective: To determine the genes specifically expressed in the immune system in SSc by analysis of the gene expression profile of peripheral blood mononuclear cells (PBMC) from patients with SSc, including those treated with haematopoietic stem cell transplantation (HSCT). Additionally, to investigate the clinical significance of the up regulation of tumour necrosis factor $\alpha$ (TNF $\alpha$ ) converting enzyme (TACE).

Methods: PBMC from patients with SSc $(n=23)$ and other autoimmune diseases (systemic lupus erythematosus (SLE, $n=16)$, rheumatoid arthritis (RA, $n=29)$ ), and from disease-free controls $(n=36)$ were examined. Complementary DNA arrays were used to evaluate gene expression of PBMC, in combination with real time quantitative polymerase chain reactions. TACE protein expression in PBMC was examined by fluorescence activated cell sorter (FACS).

Results: In patients with SSc 118 genes were down regulated after HSCT. Subsequent comparative analysis of SSc without HSCT and healthy controls indicated SSc-specific up regulation for three genes: monocyte chemoattractant protein-3 $(p=0.0015)$, macrophage inflammatory protein $3 \alpha(p=0.0339)$, and TACE $(p=0.0251)$. In the FACS analysis, TACE protein was mainly expressed on CD1 $4^{+}$monocytes both in patients with SSc and controls. TACE expression on $\mathrm{CD}_{1} 4^{+}$cells was significantly increased in patients with early SSc $(p=0.0096)$, but not in those with chronic SSc, SLE, or RA. TACE protein levels in SSc monocytes correlated with the intracellular CD68 levels $(p=0.0016)$.

Conclusions: Up regulation of TACE expression was a unique profile in early SSc, and may affect the function of TNF $\alpha$ and other immunoregulatory molecules.
\end{abstract}

S ystemic sclerosis (SSc) is a multisystem disorder of connective tissue. Increased biosynthesis of multiple matrix proteins by interstitial fibroblasts is the hallmark of SSc, with development of skin sclerosis and involvement of visceral organs. ${ }^{1}$ The pathogenesis of SSc includes vasculopathy associated with endothelial cell dysfunction, and extensive fibrosis secondary to fibroblast activation. ${ }^{23}$ Functional abnormality in $\mathrm{T}$ and $\mathrm{B}$ lymphocytes has been considered in the pathogenesis, based on the presence of disease-specific autoantibodies and hypergammaglobulinaemia in SSc. ${ }^{4}$ Growth factors and cytokines are also thought to play a part in the progression of connective tissue fibrosis in SSc. Among them, transforming growth factor $\beta$ (TGF $\beta$ ) and the Smad system have a central role in the SSc dermis. ${ }^{6}$ However, the molecular basis of the pathogenesis of SSc has remained unclear.

The use of gene expression profiling, such as the complementary DNA (cDNA) array system, is increasingly being used for various diseases, and is used in the aetiological study of SSc. ${ }^{78}$ Increased expression of several genes has been suggested, but a disease-specific gene profile of SSc has not yet been determined, possibly owing to the difficulty of achieving disease remission in SSc, which is necessary for a comparative analysis of the active and disease-free status. Recently, the efficacy of high dose chemotherapy after autologous haematopoietic stem cell transplantation (HSCT) for refractory autoimmune diseases has been reported. ${ }^{9}{ }^{10}$ HSCT has been performed in a number of cases of SSc, with good results. ${ }^{11-13}$ When we performed autologous
CD34 selected HSCT for our patients with SSc, we observed a prompt and persistent improvement of skin sclerosis and stabilisation of organ disease. Under this condition, it was possible to carry out a comparative analysis of gene expression profile between an active (pre-HSCT) and a remission status (post-HSCT) in the same patient with SSc.

We studied the gene expression profile in peripheral blood mononuclear cells (PBMC) from patients with SSc treated with HSCT, and found that expression of tumour necrosis factor $\alpha(\mathrm{TNF} \alpha)$ converting enzyme (TACE) was increased in circulating monocytes from patients with SSc. The correlation

Abbreviations: $A b$, antibody; $a C E N P-B A b$, anticentromere protein- $B$ $A b$; $A C R$, American College of Rheumatology; $A N A$, antinuclear $A b$; aRNP $\mathrm{Ab}$, anti-ribonucleoprotein $\mathrm{Ab}$; $a \mathrm{~T}$ Topo-I $\mathrm{Ab}$, antitopoisomerase I $\mathrm{Ab} ; \mathrm{CaMKII} \beta$, calcium/calmodulin dependent protein kinase II $\beta ; \mathrm{CDNA}$, complementary DNA; CRP, C reactive protein; CTGF, connective tissue growth factor; FACS, fluorescence activated cell sorter; FITC, fluorescein isothiocyanate; FSC, forward light scatter; GAPDH, glyceraldehyde-3phosphate dehydrogenase; HSCT, haematopoietic stem cell transplantation; IL, interleukin; MCP, monocyte chemoattractant protein; $\mathrm{MFI}$, mean fluorescence intensity; mlgGl, isotype matched control mouse lgGl; MIP, macrophage inflammatory protein; mRNA, messenger RNA; NF- $\kappa B$, nuclear factor- $\kappa B$; NIK, NF- $\kappa B$ inducing kinase; $\mathrm{PBMC}$, peripheral blood mononuclear cells; $\mathrm{PE}$, phycoerythrin; RA, rheumatoid arthritis; real time PCR, quantitative TaqMan real time polymerase chain reaction; RGS, regulators of G-protein signalling; SLE, systemic lupus erythematosus; SSc, systemic sclerosis; SSC, side light scatter; TACE, tumour necrosis factor $\alpha$ converting enzyme; TGF $\beta$, transforming growth factor $\beta$; TNF $\alpha$, tumour necrosis factor $\alpha$; TNF-R, TNF receptor 
Table 1 Clinical features of the study subjects*

\begin{tabular}{|c|c|c|c|c|c|}
\hline Characteristics & $\begin{array}{l}\text { SSc } \\
(n=20)\end{array}$ & $\begin{array}{l}\text { SSc treated with } \\
\text { HSCT } \\
(n=3)\end{array}$ & $\begin{array}{l}\text { RA } \\
(n=29)\end{array}$ & $\begin{array}{l}\text { SLE } \\
(n=16)\end{array}$ & $\begin{array}{l}\text { Controls } \\
(n=36)\end{array}$ \\
\hline Sex (female/male) & $17 / 3$ & $2 / 1$ & $23 / 6$ & $14 / 2$ & $25 / 11$ \\
\hline Age (years), mean (SD) & $51.0(12.6)$ & $43.3(21.1)$ & $58.9(14.4)$ & $40.5(13.4)$ & $40.0(11.5)$ \\
\hline Duration of disease (months), median (min-max) & $41.0(6-278)$ & $18(12-24)$ & $36.0(3-360)$ & $144.0(1-444)$ & \\
\hline Prednisolone (mg/day), mean (min-max) & $0.875(0-10)$ & $0.83(0-2.5)$ & $4.1(0-25)$ & $13.0(0-60)$ & \\
\hline \multicolumn{6}{|l|}{ Organ involvement, No (\%) } \\
\hline Lung & $13(65)$ & $2(67)$ & $3(10)$ & $0(0)$ & \\
\hline Muscle & $1(5)$ & $0(0)$ & $0(0)$ & $0(0)$ & \\
\hline Joint & $8(40)$ & $0(0)$ & $29(100)$ & $3(19)$ & \\
\hline Renal & $1(5)$ & $1(33)$ & $0(0)$ & $5(31)$ & \\
\hline Cardiac & $2(10)$ & $0(0)$ & $0(0)$ & $0(0)$ & \\
\hline \multicolumn{6}{|l|}{ Serology, No (\%) } \\
\hline ANA & 19 (95) & $2(67)$ & $19(66)$ & $16(100)$ & \\
\hline aTopo-I Ab & $11(55)$ & $2(67)$ & $N / A$ & $\mathrm{~N} / \mathrm{A}$ & \\
\hline$a C E N P-B$ Ab & $2(10)$ & $0(0)$ & N/A & $\mathrm{N} / \mathrm{A}$ & \\
\hline aRNP $A b$ & $1(5)$ & $0(0)$ & N/A & $11(69)$ & \\
\hline
\end{tabular}

of TACE expression with the clinical findings in patients with SSc was analysed and is discussed below.

\section{PATIENTS AND METHODS}

\section{Patients and controls}

Twenty three Japanese patients with SSc who fulfilled the 1980 criteria of the American College of Rheumatology (ACR) were assessed in this study. ${ }^{14}$ These patients were categorised as those with diffuse cutaneous type disease characterised by generalised or widespread skin thickening. ${ }^{15}$ Table 1 summarises their clinical features. Patients were classified as having early SSc $(n=12)$ if the disease duration after the appearance of the first non-Raynaud's phenomenon was within 3 years. ${ }^{11}$ Other patients with SSc with a longer disease duration were classified as having chronic SSc $(\mathrm{n}=11)$. Of the 12 patients with early SSc, three were treated with HSCT using autologous $\mathrm{CD} 34^{+}$selected peripheral blood stem cells; blood samples were obtained throughout the clinical course. Other patients with autoimmune diseases had rheumatoid arthritis (RA) or systemic lupus erythematosus (SLE). These patients fulfilled the criteria of the ACR, respectively. ${ }^{16}{ }^{17}$ As healthy controls, 36 disease-free Japanese volunteers, mean (SD) age 40.0 (11.5) years, were enrolled in the study.

\section{Study design}

To search for specific genes which changed between the active and remission status, before and after HSCT, we first analysed gene expression profiles of PBMC from patients treated with HSCT using cDNA array $(n=3)$. Next, specific up regulated genes in patients with SSc were explored using cDNA array by comparing mRNA levels in PBMC of patients with SSc who had not received HSCT $(n=6)$ and healthy controls $(n=5)$. Specific gene candidates were confirmed by real time polymerase chain reaction (PCR) in patients with SSc without HSCT $(n=9)$ and controls $(n=6)$. Finally, protein expression levels were analysed by a fluorescence activated cell sorter (FACS) analysis.

\section{PBMC isolation}

Blood sampling was carried out after obtaining written informed consent according to the guidelines of the ethical committee of Hokkaido University. PBMC were obtained from heparinised venous blood, using gradient centrifugation over Ficoll-Paque Plus (Amersham Biosciences Corp, NJ).

\section{RNA extraction and cDNA array analysis}

Total RNAs from PBMC were isolated using TRIzol reagent (Invitrogen, Carlsbad, CA). Poly(A) RNA was isolated from total RNA using a MagExtractor (TOYOBO, Osaka, Japan), and $\operatorname{poly}(\mathrm{A})$ RNA $(2 \mu \mathrm{g})$ was reverse transcribed by ReverTraAce (TOYOBO), in the presence of cDNA synthesis primers and biotin-16-deoxyuridine triphosphate (TOYOBO), according to the manufacturer's instructions. cDNA array analysis was performed using human cDNA expression filters (Human Immunology Filters (TOYOBO)), on which 621 species of human cDNA fragments and housekeeping genes are spotted in duplicate: (http://www.toyobo.co.jp/seihin/xr/ product/genenavi/genenavigator.html, accessed 5 May 2005)). Hybridisation and subsequent cDNA array analyses were carried out as described previously, ${ }^{23}$ with some modification. Briefly, after standard prehybridisation, cDNA array filters were hybridised with a biotin labelled cDNA probe in PerfectHyb solution (TOYOBO) overnight at $68^{\circ} \mathrm{C}$. After washing under conditions of high stringency, specific signals on the filters were visualised using Phototope-Star Detection Kits (New England Biolabs, Beverly, MA). Fluorescence signals for mRNA expression levels were obtained using a Fluor-S Multiimager system (Nippon BioRad Laboratories, Tokyo, Japan). The signal intensity among filters was compared in an E-Gene Navigator Analysis (GeneticLab, Sapporo, Japan), and was expressed as an mRNA expression index to the intensity of the internal glyceraldehyde-3-phosphate dehydrogenase (GAPDH) gene expression.

\section{Quantitative TaqMan real time polymerase chain reaction (real time $P C R$ )}

A two step PCR was carried out on serial dilutions of cDNA samples from PBMC from the patients with SSc and the controls. Real time PCR amplification and determination of cDNA transcripts were carried out with the ABI PRISM 7000 sequence detection system (Applied Biosystems, Foster City, CA) and gene-specific sets of TaqMan Universal PCR master mix and assays-on-demand gene expression probes (Applied Biosystems). 
Table 2 Down regulated genes expressed in PBMC from patients with SSc at 6 months after HSCT as indicated by a cDNA array

\begin{tabular}{|c|c|c|c|c|c|}
\hline Gene name & Accession No & Gene name & Accession No & Gene name & Accession No \\
\hline Bik & X89986 & MCP-2 & Y16645 & GRP94 & $\mathrm{X} 15187$ \\
\hline Caspase- 8 & U60520 & MCP-3 & X72308 & HSP105 $\beta$ & $\mathrm{AB} 003333$ \\
\hline JunB & $\times 51345$ & Neurophysin II & X03172 & MMP3 & $\mathrm{J} 03209$ \\
\hline$A P-\beta$ & X95694 & Delta & AF003522 & TACE & U86755 \\
\hline$A P-\gamma$ & X95693 & Angiotensinogen & K02215 & Cathepsin G & M16117 \\
\hline Erg-1 & $M 21535$ & $\begin{array}{l}\text { Gonadotropin } \alpha \\
\text { peptide }\end{array}$ & V00518 & Pin 1 & U49070 \\
\hline GLI-3 & M57609 & Somatostatin & J00306 & Calpastatin & U26724 \\
\hline $\operatorname{I} \mathrm{B} \alpha \alpha$ & M69043 & VIP & M36634 & Moesin & M69066 \\
\hline IRF-2 & X15949 & Gastrin & V00511 & Radixin & LO2320 \\
\hline N-Myc & M13228 & IP10 & X02530 & LAT & AF036905 \\
\hline Per2 & $\mathrm{AB} 002345$ & MIP-3 $3 \alpha$ & U77035 & Fyb & AF001862 \\
\hline Pax5 & M96944 & EphA5 & L36644 & Furin & $\times 17094$ \\
\hline LXR $\alpha$ & U22662 & EphB6 & D83492 & PAI-2 & M16006 \\
\hline $\mathrm{RXR} \gamma$ & U38480 & Insulin receptor & M10051 & $\mathrm{CD} 3 \gamma$ & $\mathrm{X} 04145$ \\
\hline RAC3 & AF010227 & $M C l-R$ & X67594 & $\mathrm{CD} 3 \epsilon$ & X03884 \\
\hline PPAR $\gamma$ & L40904 & MC4-R & L08603 & $\mathrm{CD} 3 \zeta$ & J04132 \\
\hline MCR & M16801 & $B 2-A R$ & M15169 & $\mathrm{CD} 8 \beta 1$ & $\times 13444$ \\
\hline MEK-5 & U25265 & FRP-3 & U24163 & CD5 & X04391 \\
\hline MEK kinase-2 & AF111105 & Notch 2 & AF097645 & CD72 & M54992 \\
\hline Raf-1 & X03484 & Thrombin R & M62424 & CD6 & X60992 \\
\hline Raf-B & M95712 & IFN $\gamma$ R2 & U05875 & CD7 & X06180 \\
\hline KKIAMRE & U35146 & IL2R $\gamma$ & D1 1086 & CD20 & $\times 12530$ \\
\hline Rhotekin & Al970663 & IL15R $\alpha$ & U31628 & CD27 & M63928 \\
\hline $\mathrm{IKK} \alpha$ & AF080157 & c-Kit & X06182 & $\mathrm{CD} 28$ & J02988 \\
\hline JAK1 & M64174 & CXCR-4 & AF025375 & CD35 & Y00816 \\
\hline MuSK & AF006464 & Slap & D89077 & CD38 & M34461 \\
\hline TGF $\beta 2$ & M19154 & Shb & X75342 & CD40L & L07414 \\
\hline GDF-8 & AF019627 & Sos 1 & L13858 & CD42a & $\times 52997$ \\
\hline Inhibin $\alpha$ & M13981 & $\mathrm{Dbl}$ & J03639 & CD43 & J04168 \\
\hline FGF-1 & X51943 & Ral GDS & U14417 & CD46 BC1 & M58050 \\
\hline FGF-5 & M37825 & RGS4 & U27768 & CD59 & $X 16447$ \\
\hline FGF-6 & X63454 & $\mathrm{Pl} 4-\mathrm{K} \alpha$ & AJ011121 & CD69 & L07555 \\
\hline HGF $\beta$ chain & E08541 & FRP1 & U49844 & CD74 & X03339 \\
\hline IGF-BP3 & M35878 & Sam68 & M88108 & $\mathrm{TCR} \alpha$ & U36759 \\
\hline TNF $\beta$ & D12614 & PPPICA & X70848 & TCR $\beta$ & L07294 \\
\hline IL2 & U25676 & CD45 & Y00062 & $\mathrm{TCR} \gamma$ & Y00790 \\
\hline IL10 & M57627 & p120 & AF062343 & CD138 & J05392 \\
\hline IL15 & AF031167 & Ref-1 & D90373 & ICAM3 & X69819 \\
\hline IL18 & D49950 & HSP60 & M34664 & & \\
\hline SCF & M59964 & HSP9O $\beta$ & $M 16660$ & & \\
\hline \multicolumn{6}{|c|}{$\begin{array}{l}\text { One hundred and eighteen gene expressions decreased more than } 20 \% \text { in all three patients with SSc treated wit } \\
\text { HSCT at } 6 \text { months after HSCT compared with before HSCT ( }<1 \text { month before mobilisation) by cDNA array } \\
\text { analysis. Changes in white blood cell and monocyte counts in PBMC from three patients with SSc treated with HSC } \\
\text { were from } 4867(116) / \mu l \text { to } 5100(917) / \mu \mathrm{l}\left(p=0.5105^{*}\right) \text { and from } 506(157) / \mu l \text { to } 589(44) / \mu \mathrm{l}\left(\mathrm{p}=0.7106^{*}\right. \\
\text { respectively. "Paired } t \text { test. }\end{array}$} \\
\hline
\end{tabular}

\section{FACS analysis}

The following mouse monoclonal antibodies were purchased from BD Biosciences Pharmingen (San Diego, CA): antihuman CD3-Cy-chrome, CD4-fluorescein isothiocyanate (FITC), CD8-phycoerythrin (PE) and FITC, CD56-FITC, CD19-FITC, CD68-PE, and CD69-PE. Monoclonal mouse antihuman-CD14-FITC, CD71-PE (Beckman Coulter Inc, Fullerton, CA) and antihuman TACE-PE (R\&D systems, Abingdon, UK) were also used for surface immunostaining of the cells. The specificity of antihuman TACE has been characterised. ${ }^{24}$ In the case of CD68, intracellular staining was done using Cytofix/Cytoperm Plus (BD Biosciences Pharmingen, San Diego, CA), according to the manufacturer's instructions. After washing twice with phosphate buffered saline (PBS), cells were subjected to FACS analysis of immunostained cells using a FACSCalibur flow cytometer (Becton Dickinson Immunocytometry Systems, San Jose, CA).

\section{Statistical analysis and clinical significance}

Calculations were made using the statistical software package StatView 5.0 (Abacus Concepts, Berkeley, CA). Comparisons of mRNA expression of PBMC were made using Mann-Whitney statistics. Group mean comparisons of the TACE protein expression levels, represented by mean fluorescence intensity (MFI), and TACE positive cells were based on Kruskal-Wallis $\mathrm{H}$ statistics. A paired $t$ test was used to analyse the difference in blood cell counts of patients with SSc before and after HSCT. The data are presented as the means (SD). Differences were examined based on analysis of variance, and $\mathrm{p}$ values $<0.05$ were considered significant.

\section{RESULTS}

\section{Comprehensive analysis of up regulated genes in} PBMC from patients with SSc using CDNA array and real time $\mathrm{PCR}$

We first analysed mRNA expression in PBMC from three patients with SSc treated with HSCT, in order to search for genes with expression levels down regulated after this treatment. In these patients, skin involvement, as expressed by the modified Rodnan total thickness skin score improved significantly by $54 \%$ (from 30.3 (6.8) to 12.6 (13.2)) and the modified Health Assessment Questionnaire improved by $22.8 \%$ (from $1.67(0.88)$ to $1.29(1.04)$ ) at 6 months after effective HSCT. This improvement persisted even 3 years after this treatment. PBMC specimens were obtained from these patients before $(<1$ month before mobilisation) and 6 months after HSCT, and were processed for mRNA extraction followed by cDNA array analyses. 
Table 3 Up regulated genes expressed in PBMC from patients with SSc without HSCT as indicated by a cDNA array

\begin{tabular}{|c|c|c|c|}
\hline Classification & $\begin{array}{l}\text { Up regulated } \\
\text { genes }\end{array}$ & $\begin{array}{l}\text { GenBank } \\
\text { accession } \\
\text { No }\end{array}$ & $\begin{array}{l}\text { Ratio (fold } \\
\text { increase) }\end{array}$ \\
\hline $\begin{array}{l}\text { Regulatory transcription } \\
\text { factors }\end{array}$ & $\begin{array}{l}\text { Perl } \\
\text { Erg-3 } \\
\text { Gfi-1 }\end{array}$ & $\begin{array}{l}\text { AB002107 } \\
\text { S40832 } \\
\text { U67369 }\end{array}$ & $\begin{array}{l}7.61 \\
4.50 \\
4.44\end{array}$ \\
\hline Protein kinases & CaMKII $\beta$ & AF078803 & 4.90 \\
\hline $\begin{array}{l}\text { Growth factors and } \\
\text { hormones }\end{array}$ & $\begin{array}{l}\text { IL1 } \beta^{*} \\
\text { MIP-1 } \beta^{*} \\
\text { TARC } \\
\text { IL12p35 } \\
\text { MIP-3 } \alpha^{*} \\
\text { MCP-3 }\end{array}$ & $\begin{array}{l}\text { X02532 } \\
\text { J04130 } \\
\text { D43767 } \\
\text { AF180562 } \\
\text { U77035 } \\
\text { X72308 }\end{array}$ & $\begin{array}{l}9.70 \\
6.58 \\
5.56 \\
4.27 \\
4.25 \\
3.88\end{array}$ \\
\hline Membrane receptors & IL15R $\alpha$ & U31628 & 3.46 \\
\hline Signalling intermediates & $\begin{array}{l}\text { Gabl } \\
\text { RGS-1* } \\
\text { Shb } \\
\text { TACE* } \\
\text { Dbl }\end{array}$ & $\begin{array}{l}\text { U43885 } \\
\text { X73427 } \\
\text { X75342 } \\
\text { U86755 } \\
\text { J03639 }\end{array}$ & $\begin{array}{l}6.09 \\
5.21 \\
4.32 \\
3.70 \\
3.38\end{array}$ \\
\hline Lymphocyte signalling & CD34 & M81104 & 3.40 \\
\hline
\end{tabular}

The ratio of the gene expression index (see "Patients and methods") of patients with SSc without HSCT $(n=6)$ to healthy controls $(n=5)$ was calculated, and the list of up regulated genes using CDNA array (with an $\mathrm{SSc}$ /control ratio $>3.0$ ) is displayed. *Gene expression was confirmed by real time PCR.

CaMKII $\beta$, calcium/calmodulin dependent protein kinase II $\beta ;$ MIP-1 $\beta$, macrophage inflammatory protein $\beta ; M C P-3$, monocyte chemoattractant protein-3; RGS-1, regulators of G-protein signalling-1.

At 6 months after this treatment, down regulation of mRNA expression levels was seen in 118 genes using cDNA array (table 2). In patients with SSc without HSCT, 17 genes were specifically up regulated compared with controls (table 3). In addition, the profile of mRNA expression between baseline and after 6 months in patients with SSc without HSCT was very similar, thus a "natural state for 6 months" did not modify the mRNA levels examined in this study (data not shown). Real time PCR showed that only four gene expression levels had statistical significance as diseasespecific genes in 17 patients with SSc who had not received HSCT (fig 1). As a result, gene expression levels of monocyte chemoattractant protein (MCP)-3, macrophage inflammatory protein (MIP)- $3 \alpha$, and TACE were down regulated after HSCT in the cDNA array and up regulated specifically in patients with SSc without HSCT by real time PCR (fig 2). In this study, we further investigated the expression of TACE, which has a crucial role in the immune system. A role for chemokines, including MCP and MIP families, in the pathogenesis of scleroderma has been suggested (reviewed by Atamas and White ${ }^{25}$ ).

\section{Cell surface TACE expression}

We first examined PBMC from healthy controls for the expression of TACE protein. In PBMC from healthy subjects, a small population was brightly stained by an antihuman TACE monoclonal antibody (fig 3A). Multicolour FACS analyses showed that surface TACE expression was barely detectable on $\mathrm{CD}_{4}^{+} \mathrm{CD}^{+}, \mathrm{CD}^{+} \mathrm{CD}^{+}, \mathrm{CD}^{+} 9^{+}$, and $\mathrm{CD}^{+} 6^{+}$ populations. In contrast, surface TACE expression was detected on the $\mathrm{CD} 14^{+}$population (fig $3 \mathrm{~B}$ ). It was confirmed that these $\mathrm{CD} 14^{+}$populations were monocytes, by profiles of forward and side light scatter (SSC), as well as by intracellular CD68 protein expression. Surface TACE expression levels on monocytes were not affected by the age and sex of the controls (data not shown).

We next investigated expression levels of TACE protein in subsets of PBMC from patients with SSc. In these patients, surface TACE expression was also detected on monocytes but not on $\mathrm{CD}^{+} \mathrm{CD}^{+}, \mathrm{CD}^{+} \mathrm{CD} 3^{+}, \mathrm{CD} 19^{+}$, and $\mathrm{CD} 56^{+}$populations, respectively (data not shown). Figure $3 \mathrm{C}$ shows representative FACS profiles of TACE protein expression for $\mathrm{CD} 14^{+}$
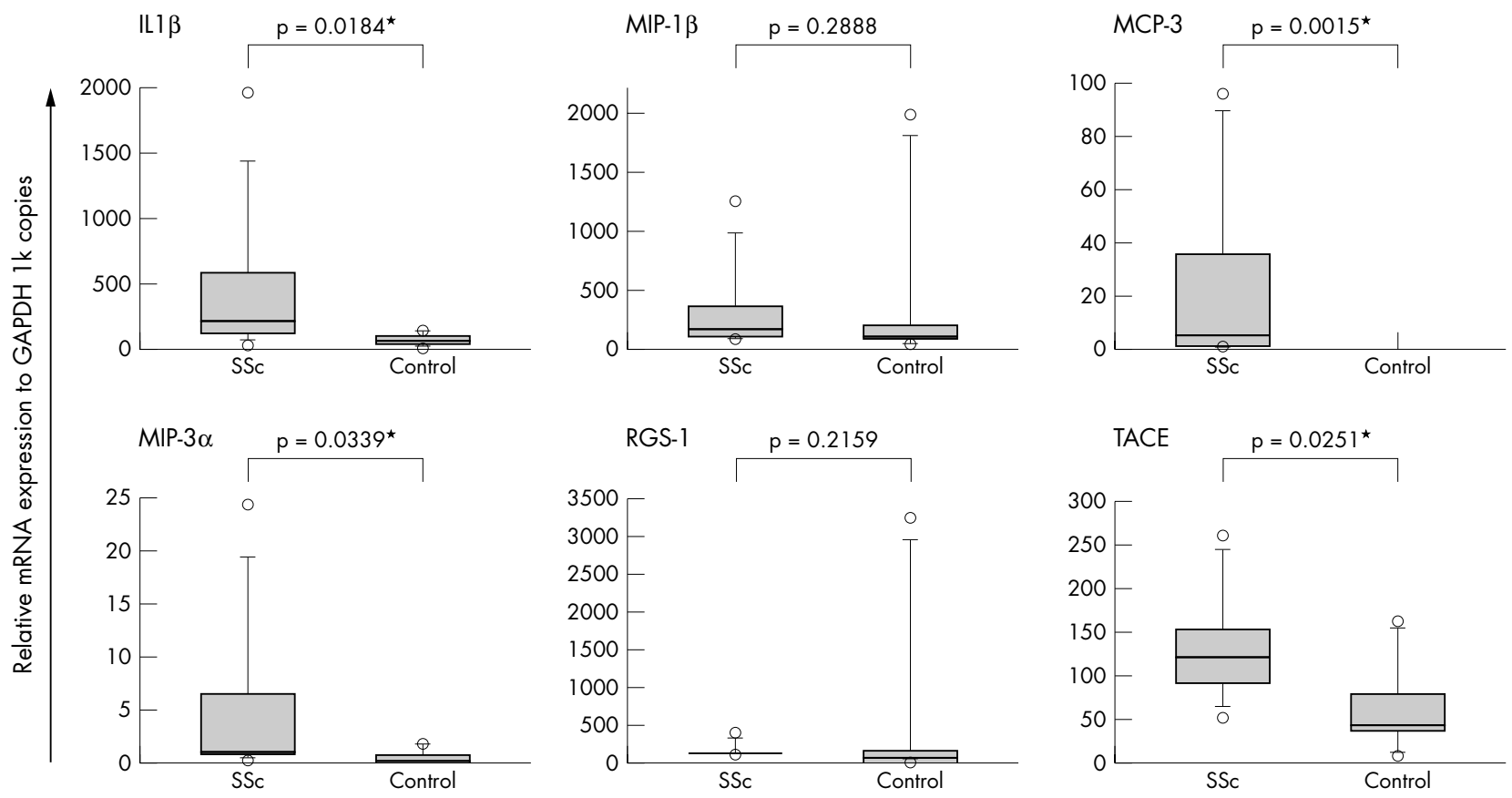

Figure 1 Quantitative analysis of up regulated genes in PBMC from patients with SSc, assessed using real time PCR. cDNA specimen from patients with SSc $(n=9)$ and disease-free volunteers $(n=6)$ were analysed for six genes species (TACE, interleukin (IL) 1 $\beta$, MIP-3 $\alpha$, MIP-1 $\beta$, MCP-3, and a regulator of G-protein signalling (RGS)-1), indicated from the cDNA array study (table 3 ). ${ }^{*} p<0.05$. 

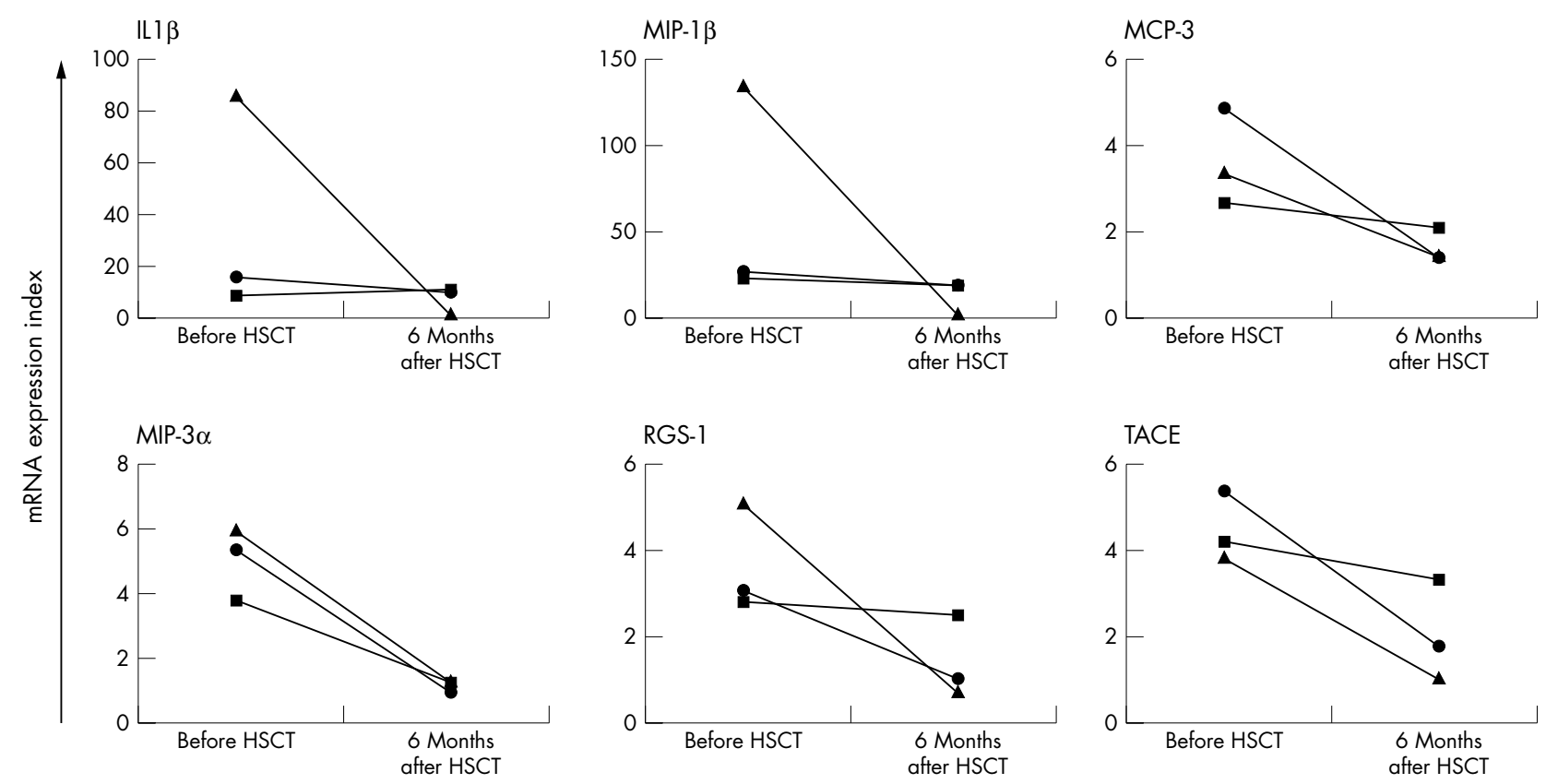

Figure 2 Changes of mRNA expression levels of IL $1 \beta$, MIP-1 $\beta$, MCP-3, MIP3- $\alpha$, RGS-1, and TACE in patients with SSc before and after HSCT using CDNA array. RNA specimens were obtained from individual patients before $(<1$ month before mobilisation) and 6 months after HSCT. Relative expression levels of mRNA were determined using CDNA arrays performed simultaneously. The expression levels of each cDNA transcript were displayed as a relative mRNA expression index compared with the levels of internal GAPDH gene expression, as described in "Patients and methods".

monocytes. In the patients with SSc, TACE expression in monocytes was significantly increased in comparison with findings in healthy controls, and in patients with RA and SLE (fig 3C). When analysed statistically, cell surface TACE protein levels of monocytes and TACE positive cells in peripheral blood were significantly increased in patients with SSc, especially in patients with early SSc with disease duration of $<3$ years, in comparison with controls and patients with non-SSc autoimmune diseases, as well as those with chronic SSc (fig 4). In addition, TACE protein levels correlated with mRNA expression levels by real time PCR $(r=0.640, \mathrm{p}=0.0462)$. Thus, we concluded that up regulated expression of TACE protein by monocytes was a unique profile of early SSc.

\section{Relationship between cell surface TACE expression and maturation/activation markers of monocytes} To better understand the mechanism of TACE up regulation in monocytes in SSc, we next investigated correlations between TACE and activation/differentiation markers of monocytes from patients with SSc. Coexpression of surface CD69, CD71, and intracellular CD68 with TACE was evaluated using FACS analysis (fig 5). These proteins were variously expressed on SSc monocytes, but only intracellular CD68 protein levels showed a significant correlation with cell surface TACE protein expression levels $(r=0.671$, $\mathrm{p}=0.0016$ ), while cell surface CD69 and CD71 proteins did not correlate.

\section{Association of cell surface TACE expression levels with clinical features of SSc}

We then analysed the correlation of cell surface TACE protein levels of monocytes from patients with SSc (including patients with early and chronic disease) with clinical features of the disease. The expression levels of TACE protein on monocytes in patients with SSc, however, did not significantly correlate with titres of autoantibodies, including antinuclear $\mathrm{Ab}$ (ANA), antitopoisomerase I Ab (aTopo-I $\mathrm{Ab})$, anticentromere protein-B Ab (aCENP-B Ab), anti-ribonucleoprotein $\mathrm{Ab}$ ( $\mathrm{aRNP} \mathrm{Ab}$ ), as well as levels of serum immunoglobulins. The TACE protein levels did not correlate either with CRP in patients with SSc (fig 4, $r=-0.216, \mathrm{p}=0.3599)$. The expression levels of TACE protein did not differ significantly between patients with SSc with or without visceral organ disease, including interstitial pneumonia and gastrointestinal complications (data not shown).

\section{DISCUSSION}

HSCT can be an effective treatment for subjects with severe autoimmune diseases, including SSc. ${ }^{11-13}$ In our three patients with SSc who received HSCT, significant improvement of skin sclerosis was promptly achieved and persisted without any immunosuppressant drug treatment. In such patients, the gene expression profile can be studied comparatively between the active and remission state of SSc, with a minimum background of therapeutic reagents. In this study we performed a cDNA analysis of PBMC from patients with SSc who had undergone HSCT. After extensive analyses, up regulation of MCP-3, MIP-3 $\alpha$, and TACE in PBMC from patients with SSc who had not had HSCT was evident.

It was notable that these genes are commonly expressed by monocytes/macrophages. In SSc, although the earliest pathological events include dysfunction of microvascular systems and dermal fibroblasts, ${ }^{26}{ }^{27}$ cells and factors that mediate such abnormalities have not been defined. Histological studies of early SSc showed that cells infiltrating the skin of patients with early stage SSc are mainly CD14 ${ }^{+}$ monocytes/macrophages, ${ }^{28}{ }^{29}$ indicating the crucial role of these cells.

A role for chemokines has been suggested in the pathogenesis of SSc. ${ }^{25}{ }^{30-32}$ Our observation about MCP-3 and MIP- $3 \alpha$ in PBMC from patients with SSc in this study is consistent with previous findings. ${ }^{33-35}$

In addition, overexpression of TACE in PBMC appeared to be a new hallmark of early stage SSc. In PBMC subpopulations, TACE protein expression was almost limited to 

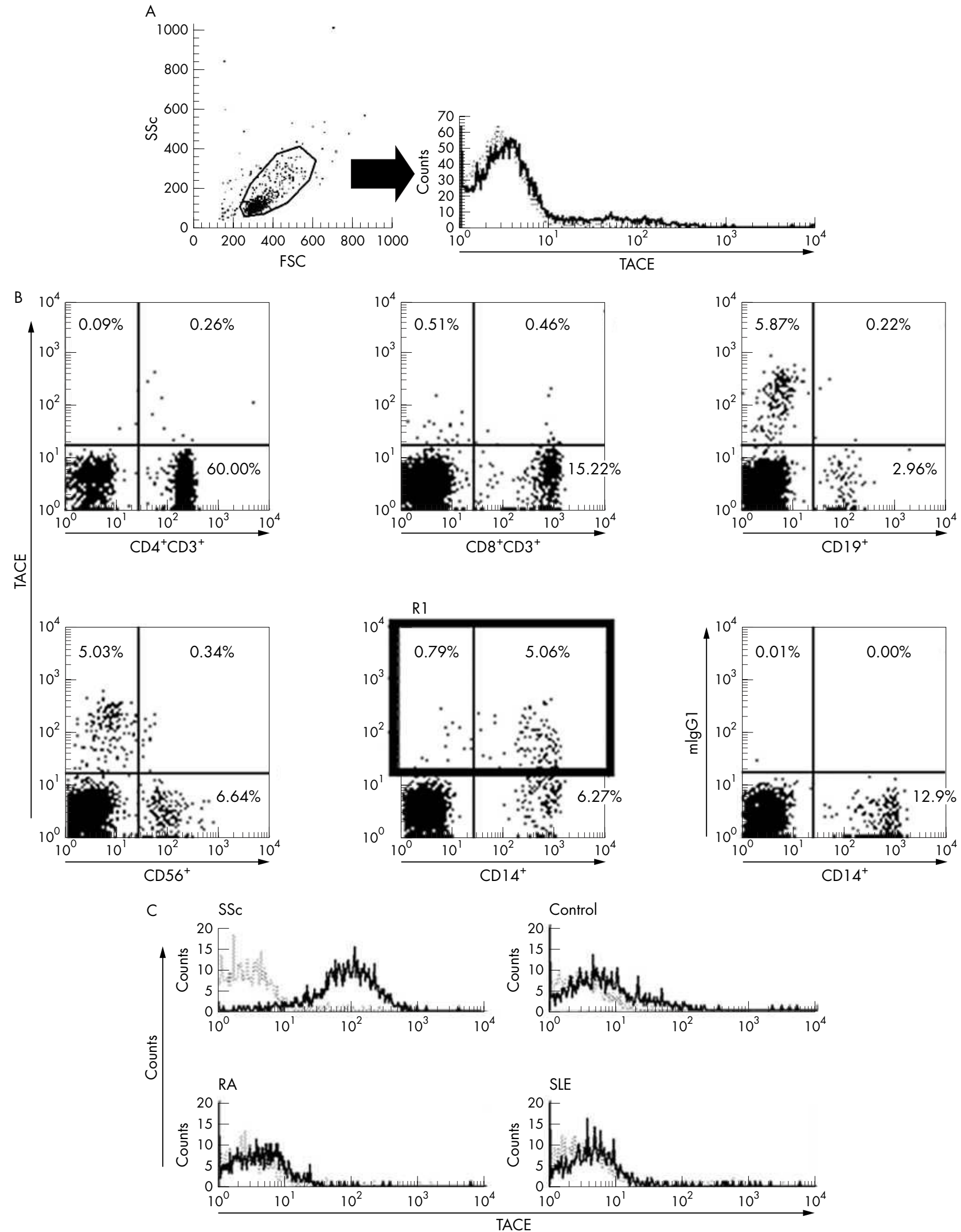

Figure 3 Expression of TACE protein in PBMC of healthy controls and patients. (A, left panel) A small population was detected in a high fluorescence intensity. ( $A$, right panel) Solid line, cells stained with anti-TACE monoclonal $A b$; dotted line, cells stained with isotype matched control mouse lgG1 Ab. (B) Expression of TACE protein in PBMC subsets from a healthy control. (C) Representative cell surface expression of TACE protein on monocytes from patients with autoimmune diseases and controls. Solid line, cells stained with anti-TACE monoclonal Ab; dotted line, cells stained with mlgG1 Ab. Results are representative of three independent experiments. 
A

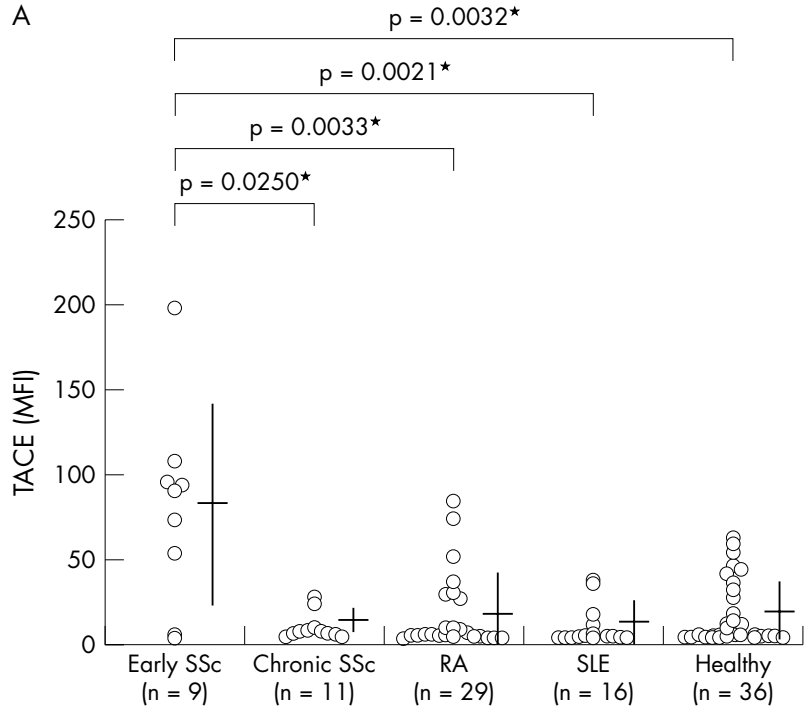

B

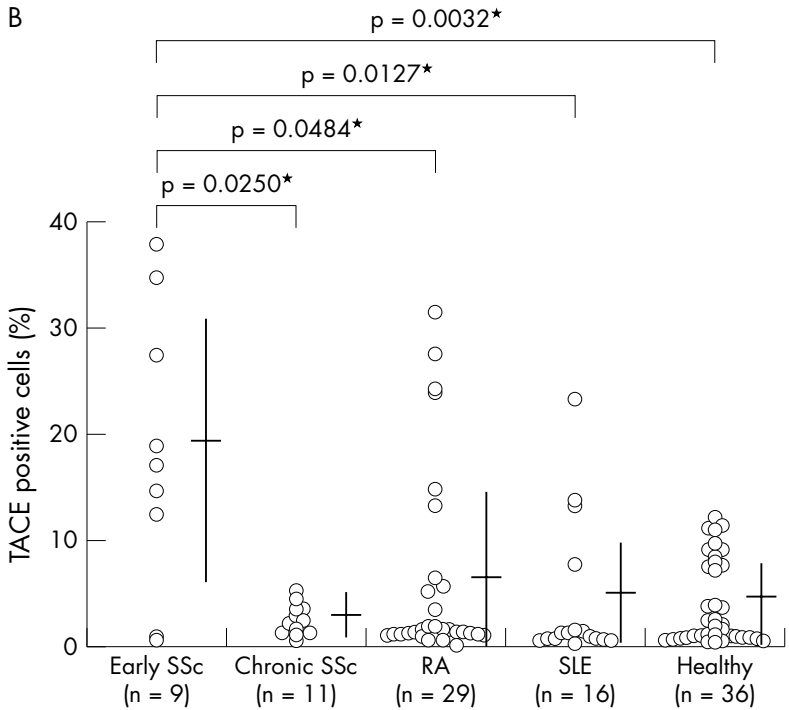

Figure 4 (A) Comparison of cell surface TACE expression by monocytes of patients with early SSc, chronic SSc, RA, SLE, and healthy controls. Cell surface expression levels of TACE were evaluated using FACS, gating on monocytes by forward and side light scatter and on CDI $4^{+}$cells. The levels of TACE protein expression were represented by the MFI. mlgGl Ab-PE staining was performed in all measurements, and showed identical levels of background staining. ${ }^{*} p<0.05$, ( $p=0.0065$ (Kruskal-Wallis H statistics)). (B) Comparison of TACE positive cells in PBMC of patients with early SSc, chronic SSc, RA, SLE, and healthy controls evaluated using FACS. TACE positive cells were defined on gate R1 in fig 3B. ${ }^{*} p<0.05$.

monocytes (fig 3B), whereas widespread distribution of TACE mRNA in tissue was suggested and its expression of protein levels in blood cells has not been yet described in detail. $^{36}{ }^{37}$ TACE protein levels on monocytes were significantly higher in SSc than in controls (figs 3C and 4), suggesting a possible association between TACE and the function of TACE-expressing monocytes with the pathoaetiology of SSc. In autoimmune diseases, up regulation of TACE in inflammatory synovial tissue from patients with RA and increased TACE mRNA expression in PBMC of patients with multiple sclerosis have been suggested, but the disease specificity has been unclear..$^{38-40}$ Our report provides the first
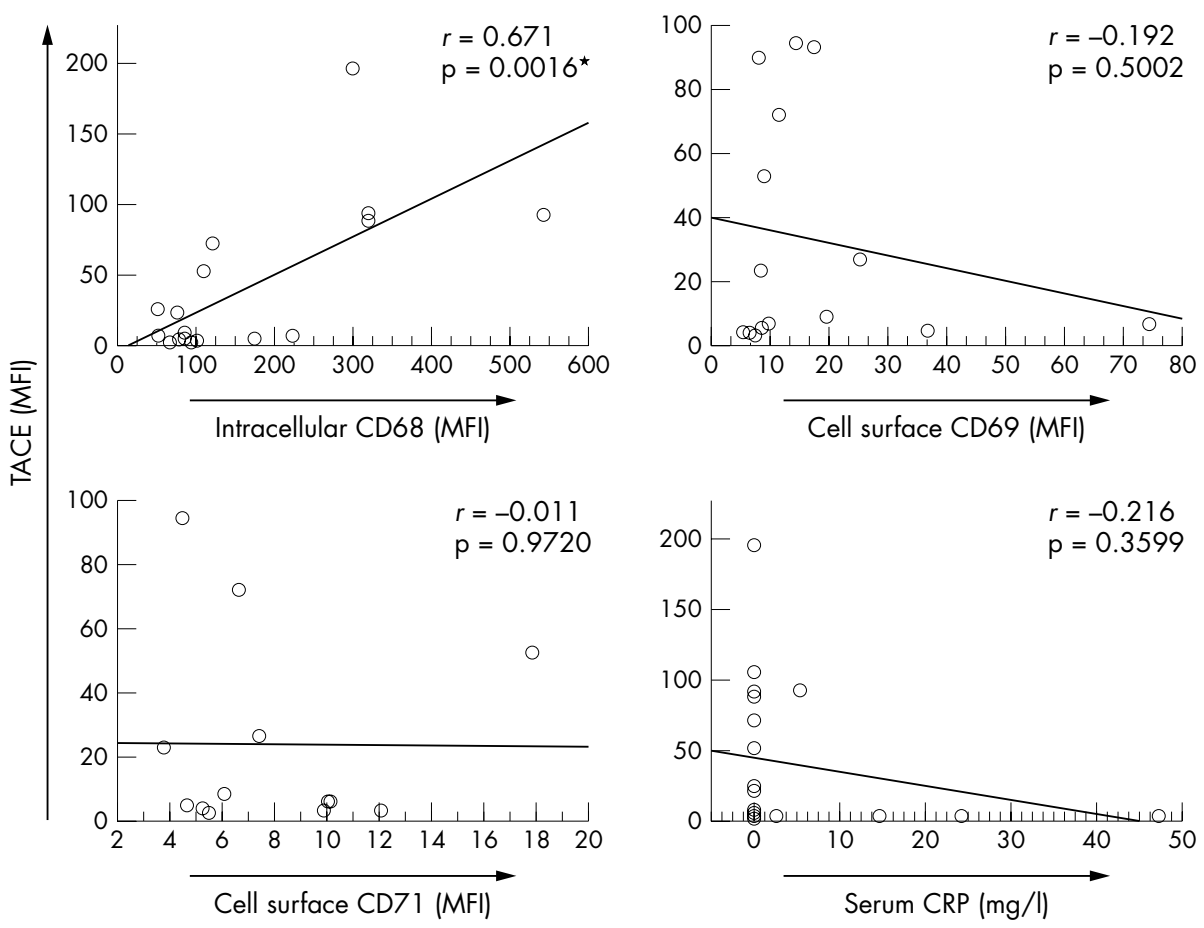

Figure 5 Correlation of TACE protein expression levels and maturation/activation markers on monocytes, and serum CRP levels in patients with SSc. Correlation of TACE protein levels with intracellular CD68 expression, cell surface CD69 expression, cell surface CD71 expression, and serum C reactive protein (CRP) levels are displayed. Cells were stained with anti-TACE-PE monoclonal antibody, or with FITC-anti-CD68, CD69, and CD71, in the presence of anti-CD14-FITC. Intracellular or cell surface levels of each marker were measured by FACS, gating on the monocytes as described above. The expression levels of individual proteins, represented by the MFI, were plotted on the horizontal axis (CD68, CD69, and CD71) and on the vertical axis (TACE), respectively. Serum CRP levels were measured by a latex agglutination test. ${ }^{*} \mathrm{p}<0.05$. 
evidence of disease-specific up regulation of TACE in peripheral monocytes in SSc, both at mRNA and protein expression levels.

TACE is a metalloproteinase of the ADAM (a disintegrin and metalloproteinase) family, and was initially described as a protease responsible for processing the membrane anchored TNF $\alpha$ precursor to the mature secreted form. ${ }^{36}{ }^{37}$ It is now accepted that substrates of TACE also include various cell surface proteins other than pro-TNF $\alpha$; TNF receptors type I (TNF-RI) and type II (TNF-RII), L-selectin, IL6 receptor $\alpha$ chain, TNF related activation induced cytokine, and fractalkine (reviewed by Mezyk et $a l^{41}$ ). TACE mRNA is expressed by various types of cells, and can be induced by various extracellular stimuli. ${ }^{41}{ }^{42}$ We found that expression of TACE increased at mRNA levels in PBMC from patients with SSC (table 3, fig 1). Moreover, expression levels of TACE protein correlated with that of intracellular CD68, a lysosomal antigen expressed during differentiation of monocytes to macrophages, and did not correlate with CD69, CD71, activation markers in blood cell, and CRP levels (fig 5). ${ }^{43}$ In patients with RA with positive CRP, surface TACE protein levels in peripheral monocytes also had no correlation $(r=$ $-0.277, \mathrm{p}=0.1459)$. Monocytes from patients with early stage SSc were likely to be activated in vivo, expressing TACE, independently of general acute reactants. Expression of TACE mRNA is regulated by transcription factors, including AP-2 and SP-1. ${ }^{44}$ Analysis of these factors may help in understanding the mechanism of TACE up regulation.

It was notable that TACE up regulation in monocytes was not seen in patients with chronic SSc with diffuse skin sclerosis (fig 4). Hence, up regulation of TACE in circulating monocytes was probably not a secondary outcome from a persistent fibrotic condition. In the pathogenesis of SSc, TGF $\beta$ and connective tissue growth factor (CTGF) dysfunction has been considered. ${ }^{85}$ In addition, the up regulated $\mathrm{TNF} \alpha / \mathrm{TNF}-\mathrm{R}$ system has also been suggested in recent studies. It has been reported that the serum soluble TNF-R levels significantly correlated with the activity and disease progression of SSc. ${ }^{46}{ }^{47}$ Furthermore, Ellman and MacDonald reported a significant improvement in the skin score of patients with SSc after administration of recombinant anti$\mathrm{TNF} \alpha$ antibody..$^{48}$ These findings are consistent with involvement of an aberrant function of the TNF $\alpha / T N F-R$ system in SSc. The up regulation of TACE may be involved in such abnormality in TNF signalling in SSc through the cleaving function of TACE.

The effect of TACE on the function of the TNF $\alpha / T N F-R$ system in vivo is not fully understood, but the soluble form of TNF $\alpha$ can interact with both TNF-RI and TNF-RII. ${ }^{49-51}$ Ligation of TNF-RI leads to recruitment of intracellular signalling proteins, resulting in the bifurcation of TNF-RI signalling: one is the apoptotic signal delivered through caspase-8, and the other is activation of proinflammatory properties delivered through nuclear factor- $\kappa \mathrm{B}(\mathrm{NF}-\kappa \mathrm{B})$ inducing kinase (NIK) and NF- $\kappa B .{ }^{52}$ Unlike TNF-RI, signalling through TNF-RII largely leads to activation of NIK dependent and NF- $\mathrm{\kappa B}$ dependent signalling. ${ }^{53}$ Thus, increased activity of TACE can shift the balance of signals mediated by distinct types of TNF receptors and downstream events, including activation or death of target cells. Interestingly, mice with a targeted mutation in TACE were perinatally lethal and had morphological defects in the skin, indicating the essential role of TACE in normal skin development. $^{54}$

Thus, it is intriguing to consider that TACE may participate in the progression of skin involvement in SSc, especially at the early stage. However, TNF $\alpha$ can also down regulate the expression of CTGF and indirectly modulate expression of type II TGF $\beta$ receptor in human fibroblasts. ${ }^{55} 56$ In addition,
TACE can also cleave other functional molecules as well as TNF $\alpha$ and the receptors. ${ }^{41}$ Such pleiotrophic action of TACE makes it difficult to predict a bona fide role of TACE up regulation in SSc. Further investigation of the function of TACE, including analysis of laboratory animals that overexpress TACE, may provide information about the significance of TACE in SSc.

In summary, this study described for the first time the aberrant expression of TACE on monocytes from patients with early SSc. Recently, several chemical compounds have been reported to inhibit the activities of metalloproteinases, including TACE. ${ }^{57}$ Such reagents may have a role in cases of TACE associated chronic inflammatory disease, including SSc. In addition, expression of TACE levels may also be a useful clinical measure of SSc, reflecting disease stages and the clinical prognosis of individual patients. Analysis of TACE function in SSc monocytes may not only provide insight into the pathogenesis but may also be a new diagnostic and therapeutic target for SSc.

\section{ACKNOWLEDGEMENTS}

We thank Ms Akiko Hirano for expert technical assistance, Drs Hiroshi Kataoka, Akira Furusaki, Katsuya Fujimoto, and Tomoyuki Endo for clinical procedures related to HSCT.

This work was supported by a national grant aid (14570004) from the Ministry of Education, Science, Technology, Sports, and Culture of Japan and a research grant for the study of the action of short fatty chain acid on cytokine gene regulation.

\section{Authors' affiliations}

T Bohgaki, Y Amasaki, M Bohgaki, Y Yamashita, M Nishio, S Jodo, T Atsumi, T Koike, Department of Medicine II, Hokkaido University Graduate School of Medicine, N-15 W-7, Kita-ku, Sapporo 060-8638, Japan

N Nishimura, Geneticlab Co, Ltd, N-27 W-6, Kita-ku, Sapporo 0010027, Japan

K-i Sawada, Department of Internal Medicine III, Akita University School of Medicine, 1-1-1 Hondo, Akita 010-8543, Japan

\section{REFERENCES}

1 Wigley FM, Hummers LK. Systemic sclerosis. In: Hochberg MC, Silman AJ, Smolen JS, Weinblatt ME, Weisman MH, eds. Rheumatology.3rd ed. Edinburgh, UK: Mosby, 2003:1455-522.

2 Furst DE, Clements PJ. Hypothesis for the pathogenesis of systemic sclerosis. J Rheumatol 1997;24(suppl 48):53-7.

3 Sakkas LI, Platsoucas CD. Is systemic sclerosis an antigen-driven T cell disease? Arthritis Rheum 2004;50:1721-33.

4 Sakkas LI, Xu B, Artlett CM, Lu S, Jimenez SA, Platsoucas CD. Oligoclonal T cell expansion in the skin of patients with systemic sclerosis. J Immunol 2002; 168:3649-59

5 Saito E, Fujimoto $M$, Hasegawa $M$, Komura K, Hamaguchi $Y$, Kaburagi $Y$, et al. CD19-dependent B lymphocyte signalling thresholds influence skin fibrosis and autoimmunity in the tight-skin mouse. J Clin Invest 2002;109:1453-62.

6 Varga J. Scleroderma and Smads: dysfunctional Smad family dynamics culminating in fibrosis. Arthritis Rheum 2002;46:1703-13.

7 Zhou X, Tan FK, Xiong M, Milewicz DM, Feghali CA, Fritzler MJ, et al. Systemic sclerosis (scleroderma): specific autoantigen genes are selectively overexpressed in scleroderma fibroblasts. J Immunol 2001;167:7126-33.

8 Luzina IG, Atamas SP, Wise R, Wigley FM, Choi J, Xiao HQ, et al. Occurrence of an activated, profibrotic pattern of gene expression in lung CD8+T cells from scleroderma patients. Arthritis Rheum 2003;48:2262-74.

9 Burt RK, Traynor AE, Craig R, Marmont AM. The promise of haematopoietic stem cell transplantation for autoimmune diseases. Bone Marrow Transplant 2003;31:521-4.

10 Tyndall A, Passweg J, Gratwohl A. Haematopoietic stem cell transplantation in the treatment of severe autoimmune diseases 2000. Ann Rheum Dis 2001;60:702-7.

11 Binks M, Passweg JR, Frust D, McSweeney P, Sullivan K, Besenthal C, et al. Phase I/II trial of autologous stem cell transplantation in systemic sclerosis: procedure related mortality and impact on skin disease. Ann Rheum Dis 2001;60:577-84.

12 Tyndall A, Koike T. High-dose immunoablative therapy with haematopoietic stem cell support in the treatment of severe autoimmune disease: current status and future direction. Intern Med 2002;41:608-12.

13 Farge D, Passweg J, van Laar JM, Marjanovic Z, Besenthal C, Finke J, et al. Autologous stem cell transplantation in the treatment of systemic sclerosis: report from the EBMT/EULAR registry. Ann Rheum Dis 2004;63:974-81.

14 ARA. Preliminary criteria for the classification of systemic sclerosis (scleroderma). Subcommittee for scleroderma criteria of the American 
Rheumatism Association Diagnostic and Therapeutic Criteria Committee. Arthritis Rheum 1980;23:581-90.

15 LeRoy EC, Krieg T, Black C, Jablonska S, Krieg T, Medsger TA Jr, et al. Scleroderma (systemic sclerosis); classification, subsets and pathogenesis. J Rheumatol 1988;15:202-5.

16 Arnett FC, Edworthy SM, Bloch DA, McShane DJ, Fries JF, Cooper NS, et al. The American Rheumatism Association 1987 revised criteria for the classification of rheumatoid arthritis. Arthritis Rheum 1998;31:315-24.

17 Hochberg MC. Updating the American College of Rheumatology revised criteria for the classification of systemic lupus erythematosus. Arthritis Rheum 1997; $40: 1725$

18 Warrick JH, Bhalla M, Schabel SI, Silver RM. High resolution computed tomography in early scleroderma lung disease. J Rheumatol $1991 ; 18: 1520-8$

19 Clements PJ, Furst DE, Campion DS, Bohan A, Harris R, Levy J, et al. Muscle disease in progressive systemic sclerosis: diagnostic and therapeutic considerations. Arthritis Rheum 1978;21:62-71.

20 Della Rossa A, Valentini G, Bombardieri S, Bencivelli W, Silman AJ, $D^{\prime}$ Angelo $S$, et al. European multicentre study to define disease activity criteria for systemic sclerosis. I. Clinical and epidemiological features of 290 patients from 19 centres. Ann Rheum Dis 2001;60:585-91.

21 Steen VD. Scleroderma renal crisis. Rheum Dis Clin North Am 1996:22:861-78.

22 Roberts NK, Cabeen WR, Moss J, Clements PJ, Furst DE. The prevalence of conduction defects and cardiac arrhythmias in progressive systemic sclerosis. Ann Intern Med 1981;94:38-40

23 Nagasako T, Sugiyama T, Mizushima T, Miura Y, Kato M, Asaka M. Up regulated Smad5 mediates apoptosis of gastric epithelial cells induced by Helicobactor pylori infection. J Biol Chem 2003;278:4821-5.

24 Contin C, Pitard V, Itai T, Nagata S, Moreau JF, Dechanet-Merville J. Membrane-anchored CD40 is processed by the tumour necrosis factor- $\alpha$ converting enzyme. J Biol Chem 2003;278:32801-9.

25 Atamas SP, White B. The role of chemokines in the pathogenesis of scleroderma. Curr Opin Rheumatol 2003;15:772-7.

26 LeRoy EC, Mercurio S, Sherer GK. Replication and phenotypic expression of control and scleroderma human fibroblasts: responses to growth factors. Proc Natl Acad Sci USA 1982:79:1286-90.

27 Prescott RJ, Freemont AJ, Jones CJP, Hoyland J, Fielding P. Sequential dermal microvascular and perivascular changes in the development of scleroderma. J Pathol 1992; 166:255-63.

28 Kräling BM, Maul GG, Jimenez SA. Mononuclear cellular infiltrates in clinically involved skin from patients with systemic sclerosis of recent onset predominantly consist of monocytes/macrophages. Pathobiology 1995;63:48-56.

29 Tamby MC, Chanseaud Y, Guillevin L, Mouthon L. New insights into the pathogenesis of systemic sclerosis. Autoimmun Rev 2003:2.152-7.

30 Galindo M, Santiago B, Rivero M, Rullas J, Alcami J, Pablos JL. Chemokine expression by systemic sclerosis fibroblasts: abnormal regulation of monocyte chemoattractant protein 1 expression. Arthritis Rheum 2001;44:1382-6.

31 Bolster MB, Ludwicka A, Sutherland SE, Strange C, Silver RM. Cytokine concentrations in bronchoalveolar lavage fluid of patients with systemic sclerosis. Arthritis Rheum 1997:40:743-51.

32 Anderegg U, Saalbach A, Haustein UF. Chemokine release from activated human dermal microvascular endothelial cells-implications for the pathophysiology of scleroderma? Arch Dermatol Res 2000;292:341-7.

33 Minty A, Chalon P, Guillemot JC, Kaghad M, Liauzun P, Magazin M, et al. Molecular cloning of the MCP-3 chemokine gene and regulation of its expression. Eur Cytokine Netw 1993;4:99-110.

34 Ong VH, Evans LA, Shiwen X, Fisher IB, Rajkumar V, Abraham DJ, et al. Monocyte chemoattractant protein 3 as a mediator of fibrosis. Over expression in systemic sclerosis and type 1 tight-skin mouse. Arthritis Rheum 2003;48:1979-91.

35 Schmuth M, Neyer S, Rainer C, Grassegger A, Fritsch P, Romani N, et al. Expression of the C-C chemokine MIP-3 $\alpha$ /CCL20 in human epidermis with impaired permeability barrier function. Exp Dermatol 2002;11:135-42.

36 Black RA, Rauch CT, Kozlosky CJ, Peschon JJ, Slack JL, Wolfson MF, et al. A metalloproteinase disintegrin that releases tumour-necrosis factor- $\alpha$ from cells. Nature 1997;385:729-33.
37 Moss ML, Jin SLC, Milla ME, Burkhart W, Carter HL, Chen WJ, et al. Cloning of a disintegrin metalloproteinase that processes precursor tumour-necrosis factor- $\alpha$. Nature 1997:385:733-6.

38 Ohta S, Harigai M, Tanaka M, Kawaguchi Y, Sugiura T, Takagi K, et al. Tumour necrosis factor- $\alpha$ (TNF- $\alpha$ ) converting enzyme contributes to production of TNF- $\alpha$ in synovial tissues from patients with rheumatoid arthritis. J Rheumatol 2001;28:1756-63.

39 Patel IR, Attur MG, Patel RN, Stuchin SA, Abagyan RA, Abramson SB, et al. TNF- $\alpha$ convertase enzyme from human arthritis-affected cartilage: isolation of cDNA by differential display, expression of the active enzyme, and regulation of TNF- $\alpha$. J Immunol 1998; 160:4570-9.

40 Seifert T, Kieseier BC, Ropele S, Strasser-Fuchs S, Quehenberger F, Fazekas F, et al. TACE mRNA expression in peripheral mononuclear cells precedes new lesions on MRI in multiple sclerosis. Mult Scler 2002;8:447-51.

41 Mezyk R, Bzowska M, Bereta J. Structure and functions of tumour necrosis factor- $\alpha$ converting enzyme. Acta Biochim Pol 2003;50:625-45.

42 Ermert M, Pantazis C, Duncker HD, Grimminger F, Seeger W, Ermert L. In situ localization of TNF- $\alpha / \beta$, TACE and TNF-receptors TNF-R1 and TNF-R2 in control and LPS-treated lung tissue. Cytokine 2003;22:89-100.

43 Allavena P, Piemonti L, Longoni D, Bernasconi S, Stoppacciaro A, Ruco L, et al. IL-10 prevents the differentiation of monocytes to dendritic cells but promotes their maturation to macrophages. Eur J Immunol 1998;28:359-69.

44 Mizui Y, Yamazaki K, Sagane K, Tanaka I. cDNA cloning of mouse tumour necrosis factor- $\alpha$ converting enzyme (TACE) and partial analysis of its promoter. Gene 1999;233:67-74.

45 Holmes A, Abraham DJ, Sa S, Shi-wen X, Black CM, Leask A. CTGF and SMADS, maintenance of scleroderma phenotype is independent of SMAD signalling. J Biol Chem 2001;276:10594-691.

46 Gruschwitz MS, Vieth G. Up-regulation of class II major histocompatibility complex and intracellular adhesion molecule 1 expression on scleroderma fibroblasts and endothelial cells by interferon- $\gamma$ and tumour necrosis factor $\alpha$ in the early disease stage. Arthritis Rheum 1997;40:540-50.

47 Gruschwitz MS, Albrecht M, Vieth G, Haustein U. In situ expression and serum levels of tumour necrosis factor- $\alpha$ receptors in patients with early stage of systemic sclerosis. J Rheumatol 1997;24:1936-43.

48 Ellman M, MacDonald PA. Etanercept as treatment for diffuse scleroderma: a pilot study [abstract]. Arthritis Rheum 2000;43(suppl 9):S392.

49 Grell M, Douni E, Wajant H, Löhden M, Clauss M, Maxeiner B, et al. The transmembrane form of tumour necrosis factor is the prime activating ligand of the $80 \mathrm{kDa}$ tumour necrosis factor receptor. Cell 1995:83:793-802.

50 Tartaglia LA, Pennica D, Goeddel DV. Ligand passing: the 75-kDa tumour necrosis factor (TNF-) receptor recruits TNF- for signalling by the 55-kDa TNFreceptor. J Biol Chem 1993;268:18542-8.

51 Grell M, Wajant H, Zimmermann G, Scheurich P. The type 1 receptor (CD120a) is the high-affinity receptor for soluble tumour necrosis factor. Proc Natl Acad Sci USA 1998;95:570-5.

52 Malinin NL, Boldin MP, Kovalenko AV, Wallach D. MAP3K-related kinase involved in NF- $\mathrm{BB}$ induction by TNF, CD95 and IL-1. Nature 1997; 385:540-4

53 Pimentel-Muinos FX, Seed B. Regulated commitment of TNF-receptor signalling: a molecular switch for death or activation. Immunity 1999:11:783-93.

54 Peschon JJ, Slack JL, Reddy P, Stocking KL, Sunnarborg SW, Lee DC, et al. An essential role for ectodomain shedding in mammalian development. Science 1998;282:1281-4

55 Abraham DJ, Shiwen X, Black CM, Sa S, Xu Y, Leask A. Tumour necrosis factor $\alpha$ suppresses the induction of connective tissue growth factor by transforming growth factor- $\beta$ in normal and scleroderma fibroblasts. J Biol Chem 2000; 275:15220-5.

56 Yamane K, Ihn H, Asano Y, Jinnin M, Tamaki K. Antagonistic effects of TNF- $\alpha$ on TGF- $\beta$ signalling through down-regulation of TGF- $\beta$ receptor type II in human dermal fibroblasts. J Immunol 2003;171:3855-62.

57 Conway JG, Andrews RC, Beaudet B, Bickett DM, Boncek V, Brodie TA, et al. Inhibition of tumour necrosis factor- $\alpha$ (TNF- $\alpha$ ) production and arthritis in the rat by GW3333, a dual inhibitor of TNF- $\alpha$-converting enzyme and matrix metalloproteinases. J Pharmacol Exp Ther 2001;298:900-8 